\title{
MEMAHAMI REKSADANA SYARIAH: INSTRUMEN KEUANGAN BERBASIS SYARIAH
}

\author{
Sumar'in \\ Fakultas Syariah dan Ekonomi Islam Institut Agama Islam (IAI) Sultan M. Syafiuddin email: \\ Email : sumarinasmawi@yahoo.co.id
}

\begin{abstract}
In finance, investment is buying or creating an asset with the expectation of capital appreciation, dividends (profit), interest earnings, rents, or some combination of these returns. This may or may not be backed by research and analysis. Most or all forms of investment involve some form of risk, such as investment in equities, property, and even fixed interest securities which are subject, among other things, to inflation risk. A mutual fund is simply a financial intermediary that allows a group of investors to pool their money together with a predetermined investment objective. The mutual fund will have a fund manager who is responsible for investing the pooled money into specific securities (usually stocks or bonds). The ruling with regards to mutual funds from an Islamic perspective can be determined by understanding the Shar'i ruling on shares and bonds.
\end{abstract}

Keywords : Invesment, Mutual Fund

\begin{abstract}
Abstrak
Di bidang keuangan, investasi adalah membeli aset dengan harapan apresiasi modal, dividen (laba), pendapatan bunga, sewa, atau kombinasi dari pengembalian ini. Ini mungkin tidak didukung oleh penelitian dan analisis. Sebagian besar bentuk investasi melibatkan beberapa bentuk risiko, seperti investasi dalam ekuitas, properti, dan sekuritas bunga tetap, antara lain, terhadap risiko inflasi. Reksa dana adalah perantara keuangan yang memungkinkan sekelompok investor untuk menyatukan uang mereka bersama dengan tujuan investasi yang telah ditentukan. Reksa dana akan memiliki manajer dana yang bertanggung jawab untuk berinvestasi dalam sekuritas khusus uang (biasanya saham atau obligasi). Putusan yang berkaitan dengan reksa dana dari perspektif Islam dapat ditentukan dengan memahami hukum Shar'i tentang saham dan obligasi.
\end{abstract}

Kata Kunci : Investasi, Resadana Syariah

\section{PENDAHULUAN}

Dalam perkembangan perekonomian, investasi merupakan salah satu pilihan yang dilakukan oleh pemilik modal untuk menge-lola dananya dengan mengharapkan imbalan yang lebih besar dimasa yang akan datang. Untuk itu, seorang investor harus 
mampu menganalisis dan mampu membuat kepu-tusan yang tepat agar mendapatkan keun-tungan sesuai harapan. Karena bagaimana-pun hal alamiah yang seringkali melekat dalam sebuah investasi adalah resiko yang senantiasa berbanding sejajar dengan tingkat keuntungan (high return and high risk).

Secara istilah investasi berasal dari bahasa inggris investment yang memiliki makna “menanam”. Dalam kamus istilah istilah Pasar Modal, Akuntansi, Keuangan dan perbankan (1999), Investasi diartikan sebagai penanaman uang atau modal dalam suatu perusahaan atau proyek yang bertujuan untuk mengharapkan keuntungan. Demikian pula menurut sharp dalam achien mem-berikan pengertian investasi sebagai suatu komitmen untuk mengorbankan dana dengan jumlah yang pasti pada saat sekarang ini untuk memperoleh dana yang tidak pasti dimasa yang akan datang. ${ }^{1}$ Dalam investasi membutuhkan perencanaan, stategi dan waktu untuk menghasilkan keuntungan. Oleh itu berbagai stategi investasi diterapkan oleh pemilik modal dalam upaya memper-oleh keuntungan dimasa yang akan datang.

Islam sebagai agama yang universal juga membenarkan praktik investasi yang dilakukan oleh pemilik modal untuk meng-harapkan keuntungan dimasa yang akan datang dengan catatan investasi tersebut harus sesuai dengan prinsip dan norma Islam. Oleh itu Islam membuat aturan (rule) yang jelas dalam dalam praktik investasi, dimana investasi dalam kerangka Islam diartikan sebagai kegiatan oleh pemilik harta (Investor) terhadap pemilik usaha (emiten) untuk memberdayakan pemilik usaha dalam melakukan usahanya dimana pemilik harta berharap akan memperoleh manfaat dimana kegiatan usahaya sangat memperhatikan prinsip kehalalan dan keadilan. ${ }^{2}$

Perkembangan model investasi yang terus meningkat menjadikan investor harus mampu membuat pilihan yang tepat dalam investasi dimana salah satu pilihan investasi yang paling familier dalam era globalisasi ini adalah investasi di Pasar modal. Dalam

\footnotetext{
${ }^{1}$ Muhammad Nadjib dkk, Implementasi Konsep Pada Kenyataan Empirik, Yogyakrat; Kreasi Wacana, 2008, Hal. 5

${ }^{2}$ Muhamad Syakir Sula, Asuransi Syariah (Life and General); Konsep dan sistem Opera-sional, Jakarta: Gema Insani Press. 2004. Hal 360.
} 
Investasi pasar Modal, salah satu pilihan yang diberikan oleh mekanisme pasar adalah adanya Invesatasi pada Reksadana.

Dalam upaya untuk memperkecil resiko dalam bisnis dipasar modal, sering-kali pemilik modal perlu melakukan inves-tasi yang menyebar pada berbagai alat investasi. Untuk investasi yang berhubungan dengan pasar modal, alat yang diperdagangkan bisa berupa saham biasa, obligasi peme-rintah, obligasi swasta dan lain-lain. Dengan banyaknya pilihan dan sarana investasi yang ditawarkan tentu akan sangat sulit untuk melakukan analisis yang tepat dalam inves-tasi tersebut, untuk itu diperlukan jasa yang memberikan bantuan pada investor untuk menyebarkan investasi tersebut sebagai upaya untuk memperkecil resiko. Perusa-haan investasi ini sering disebut reksadana atau mutual fund. ${ }^{3}$

Berdasarkan UU Pasar Modal No. 8 tahun 1995 menyatakan Reksadana adalah wadah yang digunakan untuk menghimpun dana dari masyarakat pemodal untuk selanjutnya diinvestasikan dalam bentuk porto-folio efek oleh manajer investasi. Manurung mendefinisikan reksadana adalah kumpulan dana dari masyarakat yang diinvestasikan pada saham, obligasi, deposito berjangka, pasar uang dan sebagainya. ${ }^{4}$ Veitzhal Rifa'i dkk menyatakan bahwa reksadana (Mutual Fund) adalah sertifikat yang menyatakan bahwa pemiliknya menitipkan uang kepada pengelola reksadana (fund manager) untuk digunakan sebagai modal dalam berinvestasi pada pasar uang atau pasar modal. ${ }^{5}$

Reksadana merupakan salah satu sarana investasi yang dilakukan masyarakat sebagai upaya untuk memperkecil resiko. Dalam apilikasinya perusahaan reksadana seringkali melakukan penyebaran investasi kepada beberapa instrumen-instrumen yang diyakini akan menghasilkan keuntungan. Namun bagaimanapun, tidak

\footnotetext{
${ }^{3}$ Pandji Anoraga dan Piji Pakarti, Pengantar Pasar Modal Edisi Revisi, Jakarta; Rineka Cipta, 2006, Hal 75.

${ }^{4}$ Nurul Huda dan Mustafa Edwin Nasution, Investasi pada Pasar Modal Syariah edisi Revisi, Jakarta: Kencana, 2008. Hal. 109

5 Veitzhal Rifa'i dkk, Bank and Financial Institution Management, Jakarta: Raja Grafindo Persada, 2007. Hal. 945
} 
sepenuhnya analisis yang dilakukan oleh seorang fund manager selalu tepat, untuk itu dalam upaya memperkecil resiko kerugian dari sebuah alat investasi dilakukan diversifikasi (penye-baran) investasi pada beberapa alat investasi di pasar Modal. Hal ini dengan harapan bahwa kerugian di satu alat investasi akan mampu ditutupi oleh keuntungan pada alat investasi lainnya.

Sebagai sebuah perusahaan investasi reksadana akan mempunyai hak untuk memilih saham, obligasi dan alat investasi lain-nya, yang dianggap menghasilkan keuntun-gan untuk investor. Sepenuhnya dana inves-tor menjadi tanggung jawab perusahaan reksadana untuk di sebarkan pada perusa-haan yang prospectusnya baik dalam meng-hasilkan keuntungan.

Kegiatan investasi reksadana dapat ditempatkan pada berbagai efek dan alat investasi, baik pada pasar modal atau pasar keuangan, maupaun gabungan dari kedua jenis alat investasi tersebut. Bahkan dalam praktiknya investasi reksadana juga bisa dilakukan pada pembiayaan sebauh proyek usaha. Hal ini sebagai tujuan untuk memberikan pilihan sekaligus memberikan variasi pada investasi yang menguntungkan sesuai dengan tujuan para investor.

Dalam investasi, Reksadana sering dikaitkan dengan manajemen resiko terhadap sebuah investasi dalam menghasilkan keuntungan. Setidaknya ada beberapa alasan dan kelebihan dari investari reksadana meliputi; ${ }^{6}$

1. Untuk mendapatkan tambahan uang dalam jangka panjang dan untuk di-tabung guna persiapan masa yang akan datang.

2. Untuk menghindari masalah keuangan yang kompleks dengan menyerahkan hal tersebut para pengelola professional, disisi yang lain investor dapat meraih keuntungan yang manarik setelah di-kurangi tingkat inflasi.

\section{KEUNTUNGAN REKSADANA}

6, Veitzhal Rifa'i dkk, Ibid..., Hal. 944. 
Hadirnya reksadana merupakan sebuah upaya untuk memperkecil resiko yang hadir dalam investasi, dimana dana investor diberikan pada orang yang mempunyai kemampuan yang professional untuk menge-lola dana tersebut. Keuntungan yang diberikan dari proses investasi tersebut juga mem-punyai karakteristik yang selanjutnya mam-pu membedakan jenis reksadana tersebut meliputi ${ }^{7}$;

1. Reksadana pasar uang (Money Market Funds)

Reksadana jenis ini melakukan inves-tasi pada bursa efek yang bersifat utang piutang kurang dari satu tahun. Umumnya instrument atau efek yang masuk dalam kategori ini meliputi deposito, SBI, obligasi, serta efek utang lainnya dengan tempo kurang dari satu tahun. Reksadana jenis ini merupakan reksadana yang paling kecil resikonya dalam sebuah investasi.

2. Reksadana pendapatan tetap (Fixed Income funds/FIF)

Reksadana pendapatan tetap meru-pakan reksadana yang melakukan investasi sekurang-kurangnya $80 \%$ dari portofolio yang dikelolanya kedalam efek bersifat utang, seperti obligasi dan surat utang lain-nya dan $20 \%$ dari dana yang dikelola dapat diinvestasikan pada instrument lainnya.

\section{Reksadana Saham (Equity Funds/EF)}

Reksadana jenis ini adalah reksadana yang menginvestasikan dananya sekurangkurangnya $80 \%$ pada portofolio yang ber-sifat sekuritas (saham) dan $20 \%$ lainnya diinvestasikan pada instrument lainnya.

\section{Reksadana Campuran (Balance Fund/BF)}

Reksadana ini tidak memberikan bata-san alokasi untuk suatu instrument investasi, namun seorang fund manager diberikan kebebasan untuk mengelola dana tersebut secara fleksibel sesuai dengan analisis dan prospek yang diyakininya mampu meng-hasilkan keuntungan.

1. Dilihat dari badan hukum reksadana, perusahaan reksadana dapat dibagi pada beberapa macam meliputi; Reksadana berbentuk perseorangan (Corporate Type)

\footnotetext{
${ }^{7}$ Nurul Huda dan Mustafa Edwin Nasution, Ibid. Hal. 112
} 
Dalam bentuk ini, perusahaan reksa-dana menghimpun dana dengan menjual saham dan selanjutnya dana dari hasil pen-jualan saham tersebut diinvestasikan pada berbagai jenis efek yang diperdagankan di-pasar modal atau pasar uang.

\section{Reksadana Berbentuk Kontrak Kolektif (Contractual Type)}

Bentuk kontrak investasi kolektif adalah sebagai kontrak antara fund manager dengan bank kostadian yang mengikat pemegang unit penyertaan, diman managar investasi diberikan wewenang untuk menge-lola investasi kolektif dan bank kustadian diberi wewenang untuk melakukan penitipan kolektif.

Dilihat dari sifatnya, reksadana dibagi pada dua meliputi;

1. Reksadana terbuka yaitu reksadana yang dapat menjual unit penyertaannya secara terus-menerus sepanjang masih ada investor yang berminat membeli. Se-baliknya investor dapat menjual kembali unit penyertaannya pada fund manager kapan saja sesuai keinginan.

2. Reksadana tertutup

Dalam reksadana jenis ini fund manager hanya dapat menjual sahamnya sesuai dengan batas jumlah modal dasar yang telah ditetapkan dalam anggaran dasar perseroan.

Investasi di reksadana merupakan salah satu pilihan yang didalamnya terdapat resiko dan juga return. Hal ini merupakan sesuatu yang alamiah terjadi dalam setiap investasi. Namun bila dibanding dengan alat investasi lainnya, investasi dengan instrument reksadana mempunyai resiko yang lebih terjaga dan aman.

Setidaknya terdapat lima keuntungan yang diperoleh ketika seseorang berinvestasi dalam reksadana meliputi ${ }^{8}$ :

1. Manajer Profesional

Pengelola reksadana pada umumnya terdiri atas orang-orang yang berpengalaman dan ahli dibidang pasar uang dan pasar modal. Karena dikelola oleh manajer inves-tasi yang andal, ia mencari peluang investasi yang paling baik untuk

\footnotetext{
${ }^{8}$ Veitzhal Rifa'i dkk, Ibid. Hal. 948
} 
reksadana tersebut. Pada prinsipnya manajer investasi bekerja keras untuk meneliti ribuan peluang inves-tasi bagi pemegang saham/unit reksadana, sedangkan pilihan investasi itu sendiri dipengaruhi oleh tujuan investasi dari reksa-dana tersebut.

\section{Likuiditas}

Investor yang membeli reksadana terbuka dapat menjual kembali pada penerbitnya setiap saat dan penerbit secara hukum wajib membelinya sesui dengan harga pasar yang berlaku saat itu. Dengan demikian, reksadana jauh lebih likuid dibandingkan dengan saham atau obligasi yang diperda-gangkan dibursa efek, karena untuk menjual saham harus menemukan pembeli yang ber-minat sesui dengan jumlah dan harga yang disepakati lebih dahulu. Dalam hal ini yang paling sesuai adalah reksadana untuk saham-saham yang telah dicatatkan dibursa, dimana transaksi terjadi setiap hari tidak seperti deposito berjangka atau sertifikat deposito periode tertentu.

3. Pelayanan bagi pemegang saham

Reksadana biasanya menawarkan daya tarik pada pemegang sahamnya misalnya dengan menjanjikan untuk melakukan reinvestasi terhadap deviden/capital gain secara otomatis yang seharusnya diterima nasabah.

4. Biaya rendah

Hal ini disebabkan karena perusahaan reksadana biasanya mengelola dana dalam jumlah yang besar.

\section{Diversifikasi}

Investasi dalam reksadana di back up dengan sekelompok instrument dipasar modal atau pasar uang. Kelompok instru-ment tersebut selalu berubah setiap saat agar mencapai nilai maksimum portofolio yang bersangkutan.

\section{REKSADANA SYARIAH}

Seiring dengan perkembangan jenis investasi pada pasar modal Reksadana syariah merupakan salah satu pilihan investasi yang bisa dijadikan alternative bagi masyarakat khususnya pasar muslim. Hadirnya reksadana syariah merupakan tuntutan akan investasi instrument pasar modal yang halal dan seseui dengan norma Islam, karena bagaimanapun terbitnya produk dan instru-men reksadana syariah merupakan sebuah 
perjuangan dalam upaya untuk membersih-kan praktik-praktik investasi yang mengandung unsur judi, riba dan hal-hal lain yang tidak sesaui dengan hukum Islam. Dilegalkannya produk investasi pada reksadana syariah juga memerlukan sebuah analisis dan perjalanan panjang dalam upaya untuk membumikan sistem syariah dalam setiap aktivitas ekonomi masyarakat.

Reksadana syariah mulai pertama kali diperkenankan tahun 1995 oleh national Commercial bank di Arab Saudi dengan nama Global Trade Equity dengan modal awal sebesar U\$ 150 Juta. Sedangkan untuk Indonesia Reksadana Syariah pertama kali deperkenalkan pada tahun $1997^{9}$, adalah perusahaan sekuritas milik negara PT.Danareksa menjadi pionir dalam menerbitkan reksadana syariah. Reksadana ini menjadi instrumen pasar modal pertama yang ber-operasi secara syariat islam dan sebagai langkah awal lahirnya pasar modal syariah. Salah satu jenis reksadana syariah yang menjadi topik tulisan ini adalah reksadana saham syariah.

Sesuai dengan fatwa Dewan Syariah Nasional (DSN) MUI No. 20 tahun 2001 menyatakan bahwa reksadana syariah adalah reksadana yang beroperasi menurut keten-tuan dan prinsip syariah Islam, baik dalam bentuk akad antara pemodal sebagai pemilik harta (shahibul maal/rabb al-maal) dengan manajer investasi sebagai wakil shahibul maal, maupun antara manajer investasi sebagai wakil shahibul maal dengan meng-gunakan investasi. ${ }^{10}$ Dalam Implementasi-nya Reksadana saham syariah adalah jenis reksadana yang portofolio investasinya ter-diri atas saham-saham syariah yang ter-masuk dalam kelompok saham Jakarta Islamic Index (JII) yang memenuhi syariat dan prinsip Islam, diantaranya saham peru-sahaan atau industri yang tidak bergerak dalam industri minuman keras, makanan non-halal, bank/lembaga keuangan konvensional, perjudian, senjata, hotel dan porno-grafi. Sementara dari sisi kinerja perusahaannya, antara lain dinyatakan bahwa peru-sahaan emiten tersebut tidak memiliki

\footnotetext{
${ }^{9}$ Nurul Huda dan Mustafa Edwin Nasution, Ibid. Hal. 116

${ }^{10}$ Muhammad Firdaus dkk, Briefcase Book Investasi Halal di Reksadana Syariah, Jakarta: Renaisan, 2007. Hal. 15
} 
rasio utang dengan modalnya (debt to equity ratio) atau lebih dikenal dengan DER lebih besar dari 30\%. Selain itu juga tidak memiliki pendapatan bunga lebih dari $15 \%$ pendapatan usaha riilnya dan rasio kas terhadap aktiva tidak sama dengan $100 \%$.

Metode pendapatan reksadana saham syariah dihitung berdasarkan konsep dan mekanisme syariah, dimana dalam mela-kukan transaksi tidak diperbolehkan melakukan tindakan spekulasi, yang didalamnya mengandung gharar seperti Najsy (penawaran palsu) yang lebih dikenal dengan istilah short-sale dalam pasar saham. Dana yang terkumpul dari para nasabah akan diinvestasikan kembali oleh manajer inves-tasi yang bersangkutan secara kolektif. Hasil investasinya akan ditambahkan ke akumu-lasi dana nasabah jika untung, atau dikurangi jika rugi. Akumulasi dana akan tetap menjadi milik nasabah dan disimpan pada se-buah bank kustodian yang juga berfungsi menghitung jumlah akumulasi dana. Setelah dikurangi dengan honor manajer investasi dan biaya lainnya, akumulasi dana itu di-sebut sebagai Nilai Aktiva Bersih (NAB). NAB ini akan naik turun sesuai dengan kinerja untung rugi investasi yang dilaku-kan. ${ }^{11}$

Perlu dipertegas bahwa semangat investasi dalam islam adalah menggerakkan sector riil dan memberikan bantuan modal kepada mereka yang mempunyai kemampuan usaha untuk melakukan kegiatan pro-duksi. Oleh itu Investasi dalam perspektif syariah hanya bisa dilakukan pada aktivitas ekonomi yang jelas memberikan pengaruh pada pergerakan ekonomi di sector riil sehingga pilihan investasi merupakan sebuah motivasi untuk menggerakkan modal agar tidak menetap. Dengan kata lain, tidak ada celah dalam Islam bagi masyarakat untuk men-generate kekayaannya dalam bentuk investasi. ${ }^{12}$ Demikian pula halnya dengan bentuk hukum Reksadana bila di tinjau dari persepektif syariah, sebuah ben-tuk investasi dalam reksadana harus mampu untuk memberikan kontribusi untuk mem-berikan permodalan di sector riil.

\footnotetext{
${ }^{11}$ http://www.tazkiaonline.com.mht

12 Jusmaliani, Investasi Syariah Imple-mentasi Konsep pada Kenyataan Empirik, Yogyakarta: Kreasi Wacana, 2008, Hal. 174
} 
Pada prinsipnya setiap sesuatu dalam muamalah adalah halal (boleh) selama tidak bertentangan dengan syariah Islam. Sebagai-mana sebuah kaidah figh menegaskan bahwa "prinsip dasar dari transaksi Muamalah adalah Boleh selagi tidak ada nash yang menyatakan keharaman terhadap transaksi tersebut" Allah juga memerintahkan orang yang beriman agar memenuhi akad yang mereka lakukan sebagai mana firmannya dalam Al-Qur'an yang artinya "Hai orang-orang yang beriman, penuhilah aqad-aqad itu. Dihalalkan bagimu binatang-binatang ternak, kecuali yang akan dibacakan ke-padamu. (Yang demikian itu) dengan tidak menghalalkan berburu ketika kamu sedang mengerjakan haji. Sesungguhnya Allah menetapkan hukum-hukum menurut yang dikehendaki-Nya. (QS. 5:1)’”.

Melihat pada sistem Reksadana kon-vensional terdapat sebuah hal sacral yang dilupakan yakni masalah akad. Hal ini men-jadikan praktik Reksadana dalam konsep ini dipertanyakan ke jelasan hukunya dalam konsep Islam. Walaupun pada dasarnya semangat permodalan dan kerja sama di-benarkan namun ketika transaksi tersebut tidak mencantumkan akad yang jelas maka dikhawatirkan akan menimbulkan pendzaliman dalam bentuk kerjasama tersebut.

Islam memberikan aturan yang sangat jelas dalam transaksi bisnis dan kerjasama tersebut. Hal ini sebagai upaya untuk menghilangkan praktik gharar, judi, maisyir dan pendzoliman dalam kerjasama tersebut. Sebagimana dapat dilihat dalam Firman Allah swt QS. Annisa/4 : 29.

Aturan-aturan tersebut memberikan gambaran mekanisme yang jelas untuk mendukung konsep Reksadana yang di-benarkan Syariah. Mekanisme operasional antara pemodal dan fund manager dalam reksadana syariah menggunakan sistem wakalah dimana fund manager mendapat mandat dari investor untuk mengelola dana tersebut pada jenis investasi yang meng-untungkan. Selain itu aturan terhadap jenis investasi juga dibuat dimana investasi hanya dilakukan pada jenis usaha yang benarbenar sesuai dengan prinsip Islam. Selain itu untuk menjamin Reksadana Syariah terus pada koridor syariah maka operasional reksadana syariah akan men-dapatkan pengawasan oleh Dewan Peng-awas Syariah (DPS). Hal lain yang juga menjadikan 
institusi ini diakui kemurnian-nya adalah reksadana syariah hanya mem-beli saham yang sudah melalui proses screening dimana efek ini aktivitas usahnya terhindar dari unsur haram. ${ }^{13}$

Pada dasarnya tujuan utama dari se-buah investasi dalam perspektif Islam adalah bagaimana memberikan bantuan modal untuk pada sebuah usaha atau aktivitas bisnis yang kekurangan modal. Oleh itu ruh utama dalam investasi syariah adalah produksi atau usaha, yang akan menimbul-kan lapangan kerja dan memberdayakan masyarakat dalam upaya pemerataan penda-patan. Selain itu investasi juga mempunyai tujuan untuk menghindari penumpukan harta yang tidak berguna dalam menggerakkan sector rill.

Demikian pula halnya dengan inves-tasi pada reksadana syariah, investasi ini sangat berguna dalam upaya untuk meng-gerakkan sector bisnis dan usaha, dimana salah satu karakteristik penggunaan modal dalam reksadana syariah tidak dibenarkan untuk digunakan dalam pasar derivative, dan sector keuangan yang mengandalkan bunga sebagai instrument utama dalam penentuan hasilnya (return).

Menurut Muhammad Firdaus dkk, tujuan reksadana syariah dapat disejajarkan dengan social responsible investment (SRI) atau etichal investment socially aware investment, dan value-based invasment. Tujuan utama reksadana syariah bukan ematamata mencari keuntungan, tetapi juga memiliki tanggung jawab social ter-hadap lingkungan, komitment terhadap nilai-nilai yang diyakini tanpa harus mengabaikan keinginan investornya.Dalam perkembangan bisnis dengan konsep social responsible investment (SRI) juga harus melihat setidaknya 4 (empat) aspek meliputi: ${ }^{14}$

Pertama, Social research aspek ini diperlukan untuk mencari perusahaan-perusahaan dengan management yang baik dan resiko rendah. Dalam screening terhadap perusahaan, menurut Kerr \& Zubevich hal-hal yang mereka lakukan meliputi, a)

\footnotetext{
${ }^{13}$ Nurul Huda dan Mustafa Edwin Nasution, Ibid. Hal. 122

${ }^{14}$ Jusmaliani, Investasi Syariah Imple-mentasi Konsep pada Kenyataan Empirik, Yogyakarta: Kreasi Wacana, 2008, Hal. 66
} 
negative screens seleksi ini mengharuskan fund manager mengeliminasi jenis-jenis aktivitas dan investasi yang tidak sesuai dengan tujuan investor. b) Positive screens dimana fund manager akan memberi prevensi pada investasi yang dinilai ber-tanggung jawab pada lingkungan. c) best of sector screens dimana semua perusahaan dibuat peringkatnya dengan criteria social dan lingkungan lalu investasi dilakukan hanya pada perusahaan yang retingnya tinggi. Kedua, shareholder advocacy dimana subjektivitas nilai-nilai individu perlu diper-timbangkan, karena apa yang disebut etis oleh satu individu belum tentu dianggap etis oleh yang lainnya. Misalnya aborsi, bisnis senjata dan lain-lain. Ketiga, social venture capital dimana menempatkan dananya pada tahap awal akan menjamin perusahaan dengan pendanaan yang dibutuhkan dan sering memberi keuntungan yang sehat bagi pemilik saham. Keempat, community inves-ting dalam hal ini perusahaan akan mem-berikan kredit yang terjangkau pada masya-rakat dalam menunjang usahannya.

Dengan diterapkannya sistem permo-dalan yang tepat sasaran diharapkan akan sangat membantu dalam menggerakkan sek-tor riil yang prospektif dan membawa maslahah serta mampu memberikan keun-tungan materiel pada pemilik modal.

\section{RESIKO DAN PENILAIAN REKSADANA SYARIAH}

Reksadana Syariah sebagai salah satu alat investasi mempunyai merupakan sebuah alat investasi yang mempunyai kejelasan bentuk kerjasama dan pengawasan yang sangat kuat. Mekanisme kerja dalam reksa-dana syariah juga setidaknya melibatkan tiga pihak meliputi fund manager, bank konsto-dian, serta pelaku perantara. Reksadana sya-riah setidaknya mempunyai ciri-ciri me-liputi: ${ }^{15}$

1. Mempunyai dewan Syariah yang ber-tugas memberikan arahan kegiatan fund manager.

\footnotetext{
${ }^{15}$ Muhammad Firdaus dkk, ibid. Hal. 22
} 
2. Hubungan antara investor dan perusa-haan didasarkan pada sistem mudha-rabah, dimana investor merupakan pihak yang memberikan modal dan fund manager merupakan pengelola dana.

3. Kegiatan usahanya atau investasinya diarahkan pada hal-hal yang tidak bertentangan dengan syariah Islam.

Sebagaimana halnya dalam investasi lain, keuntungan juga merupakan salah satu tujuan yang diharapkan dalam investasi rek-sadana syariah. Seorang investor juga harus melakukan analisis terhadap fund manager yang diamanahkan untuk mengelola asset. Untuk menilai seorang fund manager penilaian tersebut sangat terkait dengar reputasi reputasi seorang fund manager dalam mengelola dana investor. Untuk melihat reputasi tersebut dinilai melalui ${ }^{16}$;

1. Pengalaman dari Seorang Fund mana-ger; hal ini sangat relevan untuk menilai kemampuan seorang fund manager.

2. Keberadaan seorang fund manager, ini sangat penting dalam upaya melihat dan menilai pertanggungjawaban fund mana-ger.

3. Co-investment dimana minimal seorang fund manager ikut menginvestasikan dananya pada pembiayaan property tersebut minimal $10 \%$. Hal ini sebagai upaya turut sertanya pembangunan dan kemajuan sebuah proyek.

4. Key personal (actor kunci). Perlu diper-hatikan siapa yang menjadi penanggung jawab dalam perusahaan reksadana tersebut.

Bagi seorang fund manager penilaian terhadap portofolio juga harus dilakukan, hal ini sebagai upaya untuk menjaga asset investor agar memperoleh keuntungan. Setidaknya ada dua hal penting yang harus dipertimbangkan dalam mengukur kinerja reksadana saham syariah, yaitu:

${ }^{16}$ Sohail Jaffer, Islamic Asset Mana-gement; Forming the Future for Sharri'a-Compliant Investment Strategy, Euro Money Books, United Kingdom 2004, Hal, 144 
1. Tingkat hasil (rate of return) yang diper-oleh sama atau lebih besar dari tingkat hasil portofolio (return portofolio) ter-tentu dengn risiko yang sama atau lebih kecil dari tingkat risiko pasar (market risk).

2. Melakukan diversifikasi sehingga dapat mengelimir risiko yang tidak sistematis yang diukur dengan menghitung korelasi antara tingkat hasil reksadana saham syariah dengan tingkat hasil reksadana saham syariah dengan tingkat hasil portofolio pasar.

Secara umum asset yang terdapat dalam rekasadana syariah dibagi dalam 3 kelompok besar yaitu equity, balance dan sukuk. Sukuk ini berbada dengan instrument yang berbasis hutang sebagai usaha pokok yang dilarang dalam islam dimana sukuk ini merupakan sebuah bentuk kepemilikan terhadap satu proyek serta diterbitkan atas dasar underlying transaction atas akad syariah. ${ }^{17}$ Jenis asset yang terdapat dalam reksadana syariah memberikan peluang berkembangnya praktik spekulasi yang berlangsung dalam pasar modal. Hal ini menuntuk perlunya sebuah analisis panjang dalam upaya menghindari praktik spekulasi dalam investasi reksadana syariah hal ini sebagai upaya untuk menjaga kemurnian dan kejelasan pasar di modal syariah.

Spekulasi merupakan salah satu varia-bel yang menjadikan hancurnya perekonomian suatu Negara. Sikap spekulasi yang sering terjadi di pasar modal, demikian pula pada investasi Reksadana menjadi sebuah catatan penting untuk mampu dihapuskan atau setidaknya diminimalisir dalam instru-ment investasi syariah. Karena bagaimanapun sebagai sebuah instrument investasi yang berbasis syariah, Reksadana Syariah harus dapat membuat mekanisme baru yang lebih transparan dan riil dilapangan.

Dalam upaya menghilangkan praktik spekulasi tersebut Metwally memberikan gagasan dengan membuat jangka waktu minimum untuk menahan sebuah asset (saham) dalam satu periode minimal 3 bulan. Selain itu juga menyarankan perlunya mekanisme harga yang transparan dengan diberikannya batas harga maksimun dan

\footnotetext{
${ }_{17}$ Jusmaliani, Investasi Syariah Imple-mentasi Konsep pada Kenyataan Empirik, Yogyakarta: Kreasi Wacana, 2008, Hal. 178
} 
minimum dalam penciptaan harga pasar di bursa, hal ini dengan tujuan agar spekulasi yang terjadi pada bursa mampu untuk diminimalisir. ${ }^{18}$ Namun dalam aplikasinya konsep ini sepenuhnya sulit untuk dilakukan karena hal ini sangat terkait dengan tuntutan kebutuhan likuiditas investor yang tidak bisa diprediksi. Selain itu konsep batasan harga maksimun dan minimum sesung-guhnya sudah diterapkan pada praktik perda-gangan pasar modal konvensional namun sepenuhnya tidak mampu untuk mencegah sikap spekulasi yang dilakukan oleh inves-tor.

Dalam persepktif syariah perlu diper-tegas bahwa larangan spekulasi bukanlah pada ketidakpastian yang dihadapi dalam sebuah transaksi akibat perubahan harga, spekulasi adalah hal alamiah yang pasti ter-jadi namun sikap spekulan untuk mengharapkan keutungan dengan menjadikan spekulasi sebagai bentuk gameling merupakan hal yang terlarang dalam Islam. Hal ini terjadi ketika seseorang meninggalkan sense of responsibility dan rule of law-nya untuk memperoleh keuntungan semata dari ketidakpastian, hal ini dikategorikan sebagai praktik gharar dan maysir yang terlarang. Selain itu salah satu upaya yang dapat di-lakukan untuk mencegah spekulasi adalah dengan menerapkan celling price berdasar kan pasar perusahaan. Lebih lanjut Akhram Khan menambahkan untuk mencegah spe-kulasi maka jual beli saham harus diikuti dengan serah terima bukti kepemilikan fisik saham yang diperjual belikan.

Diakui atau tidak perkembangan inves-tasi syariah dewasa ini cukup meyakinkan. Hal ini karena perubahan karakter investasi yang terjadi dalam jangka waktu sekarang ini. Dimulai dari kemunculan perbankan syariah sebagai pioneer, jenis-jenis investasi syariah lain juga ternyata mampu memberi-kan warna dalam memberikan perlawanan terhadap sistem investasi konvension seka-rang ini. Demikian pula halnya dengan instrument investasi pada reksadana syariah. Dalam skala nasional, diawali dari PT.Danareksa menjadi pionir dalam menerbitkan reksadana syariah saat ini sudah tercatat beberapa perusahaan besar yang menjalan-kan prinsip kerjanya sesuai dengan syariah.

\footnotetext{
${ }^{18}$ Mochtar M. Matwallay In Sheikh Ghazali Sheckh Abod,, An Intoduction to Islamic Finance, Quill Publishers: Malaysia, 1992, Hal. 346
} 
Perusahaan tersebut meliputi BNI Dana Syariah, Dompet Duafa Batasa Syariah, PNM Amanah Syariah, IPB Syariah, Batasa Syariah, AAA Syariah Fund dan beberapa perusahaan lainnya.

Dilihat dari segi return Reksadana syariah bila dibandingkan dengan reksa dana konvensional masih sangat kecill. Hal ini disebabkan terbatasnya kebaradaan reksadana syariah bila dibandingkan dengan reksadana konvensional, juga dikarenakan reksadana syariah merupakan pemain baru dibanding reksadana konvensional. Selain itu investasi reksadana syariah yang sangat ketat demi dengan mekanime screening dalam upaya pemurnian usaha menjadikan jenis usahanya sangat minim dan terbatas berbeda dengan reksadana konvensional yang berbisnis dalam sector usaha apapun tanpa melihat nilai dan atauran agama.

Dilihat dari data selama periode 2002-2004, menunjukkan bahwa rata-rata return reksadana saham syariah secara individual lebih tinggi dari rata-rata tingkat return pasar berdasarkan JII. Nilai rata-rata tingkat return pasar yang dihasilkan sebesar 0,40\% ber-dasarkan pada perhitungan akumulasi return ke-30 efek dalam JII selama periode 2002-2004. Kelima reksadana saham syariah yang memiliki rata-rata tingkat return yang lebih tinggi dari tingkat return pasarnya adalah Rifan Syariah (ekuitas) 1,4078\%; Danareksa Syariah Berimbang 1,2767\%; Danareksa Syariah 1,2671\%; PNM Syariah 0,9207\%, dan BATASA Syariah 0,7622\%. Sementara dari tingkat risiko, menunjukkan rata-rata risiko reksadana saham syariah lebih rendah dari risiko pasar (JII). Dengan demikian dapat kita simpulkan bahwa umumnya reksadana saham syariah secara individu dilihat dari sisi risiko berkinerja baik. Me-masuki tahun 2005, prospek investasi reksa-dana saham syariah cukup menjanjikan, hal ini ditunjukkan oleh perkembangan pasar saham yang cukup pesat selama dua bulan terakhir dimana return pasar JII dari tanggal 3 Januari 2005 sampai 22 Februari 2005 sebesar 7,16 persen sementara return pasar secara keseluruhan yang ditunjukkan oleh IHSG sebesar 9,89 persen. $^{19}$

\footnotetext{
${ }^{19}$ http://www.tazkiaonline.com.mht
} 
Terdapat beberapa strategi yang bisa dilakukan untuk memperbaiki sekaligus mempercepat mekanisme pasar dan pergera-kan reksadana dipasar modal syariah. Ada-pun strategi tersebut meliputi ${ }^{20}$;

1. Perlunya regulasi yang tepat untuk men-dorong perkembangan pasar modal syariah atau setidaknya menyempurnakan UUPM No. 8 tahun 1995.

2. Perlunya keaktifan dari pelaku bisnis muslim untuk membentuk kehidupan ekonomi yang Islami.

3. Diperlukan rencana jangka panjang dan jangka pendek oleh Bapepam untuk mengakomodir perkembangan instru-ment dalam pasar modal.

4. Perlunya kajian yang lebih massif ter-hadap mekanisme pasar modal syariah.

\section{PENUTUP}

Reksadana syariah sebagai salah satu instrument dipasar modal merupakan salah satu lembaga keuangan syariah non-bank yang dapat dijadikan pilihan dalam berinvestasi bagi masyarakat yang ingin memperoleh return investasi dari sumber dan cara yang bersih dan dapat dipertang gungjawabkan secara syariah. Berdasarkan Pemaparan makalah diatas, setidaknya ter dapat beberapa benang merah yang bisa kita ambil meliputi;

1. Reksada Syariah merupakan salah satu bentuk investasi yang paling aman dan mempunyai resiko yang lebih stabil bila dibanding instrument lain.

2. Dalam upaya menjaga makanisme sya-riah dalam reksadana maka dalam sis-tem operasionalnya ditunjuk dewan Pengawas syariah.

3. Bagaimanapun upaya mengembangkan reksadana syariah, masih memerlukan dukungan dan kerja keras semua pihak baik akademisi, praktisi maupun semua lapisan masyarakat.

\section{DAFTAR PUSTAKA}

${ }^{20}$ Nurul Huda dan Mustafa Edwin Nasution, Ibid. Hal. 81 
Jusmaliani, Investasi Syariah Implementasi Konsep pada Kenyataan Empirik, Yogyakarta: Kreasi Wacana, 2008

Mochtar M. Matwallay In Sheikh Ghazali Sheckh Abod,, An Intoduction to Islamic Finance, Quill Publishers: Malaysia, 1992

Muhammad Firdaus dkk, Briefcase Book Investasi Halal di Reksadana Syariah, Jakarta: Renaisan, 2007

Muhammad Nadjib dkk, Implementasi Konsep Pada Kenyataan Empirik, Yogyakrat; Kreasi Wacana, 2008

Muhamad Syakir Sula, Asuransi Syariah (Life and General); Konsep dan sistem Operasional, Jakarta: Gema Insani Press. 2004

Nurul Huda dan Mustafa Edwin Nasution, Investasi pada Pasar Modal Syariah edisi Revisi, Jakarta: Kencana, 2008.

Pandji Anoraga dan Piji Pakarti, Pengantar Pasar Modal Edisi Revisi, Jakarta; Rineka Cipta, 2006,

Sohail Jaffer, Islamic Asset Management; Forming the Future for Sharri'a-Compliant Investment Strategy, Euro Money Books, United Kingdom 2004 